\title{
Is Multi-detector Computed Tomography an Early Predictor for Esophageal Injury Following Acute Caustic Ingestion?
}

\author{
Amira $\mathrm{YA}^{1}$, Manal $\mathrm{AA}^{1}$, Khaled $\mathrm{AA}^{2}$ and Hend $\mathrm{E}^{1}$ \\ ${ }^{1}$ Department of Forensic Medicine and Clinical Toxicology, Poison Control Center, Faculty of Medicine, Ain Shams \\ University Hospitals, Cairo, Egypt.
}

2 Department of Radiology, faculty of medicine, Ain Shams University, Cairo, Egypt.

\begin{tabular}{|c|c|}
\hline \multirow[t]{2}{*}{ Abstract } & $\begin{array}{l}\text { Background: Caustic ingestion is considered severe condition with poor outcome that mandate } \\
\text { early diagnosis to improve the management. Although endoscopy is considered the gold standard } \\
\text { of diagnosis worldwide, some authors urge caution in developing treatment plans for patients } \\
\text { with caustic ingestion based only on endoscopic findings. Besides, it is not considered as routine } \\
\text { management at Ain Shams University hospitals. Recent studies suggests that computed } \\
\text { tomography (CT) scan can accurately predict risk of stricture formation and also guide towards } \\
\text { more judicious use of surgical management. } \\
\text { Aim of the Work: Evaluating the role of Multi-detector Computed Tomography (MDCT) as an } \\
\text { early predictor for esophageal injury following acute caustic ingestion and comparing MDCT } \\
\text { grading system and DROOL score, for patients with acute caustic ingestion. } \\
\text { Subjects and Methods: A prospective cohort study carried out on } 50 \text { pediatric patients admitted } \\
\text { to Poison Control Center-Ain Shams University Hospitals (PCCASUHs) with history of } \\
\text { corrosive ingestion within } 24 \text { hours post ingestion. } \\
\text { Results: In the current study, (25.6\%) of the patients included in the current study had } \\
\text { esophageal injury while ( } 74.4 \%) \text { of them had no esophageal injury. DROOL score ( } 4 \text { ) could } \\
\text { predict the development of esophageal injury with sensitivity of (90.9\%), specificity of ( } 81.2 \% \text { ) } \\
\text { and accuracy of ( } 83.7 \% \text { ), } 62.5 \% \text { positive and ( } 96.3 \%) \text { negative predictive values. Also CT } \\
\text { grades III and IV could predict the development of esophageal injury with sensitivity of (90.9\%), } \\
\text { specificity of ( } 87.5 \% \text { ) and accuracy of ( } 88.4 \% \text { ), ( } 71.4 \% \text { ) positive and (96.6\%) negative } \\
\text { predictive values. } \\
\text { AUC for CT grading system (AUC = 0.88) was larger than that for the DROOL scoring system } \\
\text { (AUC =0.83). CT grading system had higher specificity and accuracy than DROOL score. } \\
\text { Conclusion and Recommendations: The current study concluded that CT grading system can } \\
\text { be used as an early predictor for esophageal injury following acute caustic ingestion. It is } \\
\text { recommended to evaluate the esophageal injury by doing MDCT for all cases admitted with } \\
\text { caustic ingestion even those with mild signs and symptoms. }\end{array}$ \\
\hline & Received in original form: 8 December 2021 Accepted in a final form: 30 December 2021 \\
\hline Key words & $\begin{array}{l}\text { Corrosive ingestion Computed Tomography (CT), Multi-detector Computed Tomography } \\
\text { (MDCT), Caustic ingestion outcome, DROOL }\end{array}$ \\
\hline
\end{tabular}

\section{Introduction}

cute ingestion of caustic agents continues to
be a significant problem world-wide
especially in developing countries mainly in
pediatric age group (Agarwal et al., 2020). The
Annual report of Poising Control Center Ain Shams
University hospitals (PCCASUH) concluded that the
third common cause of non-drug poisons was due to exposure to corrosive agents. Moreover, pediatric cases constituted $44.1 \%$ of total admitted cases during 2009 to 2013 year and $26.3 \%$ of them suffered from acute caustic ingestion (Azab et al., 2016). Stricture formation is the most common and disabling long-term complication of corrosive ingestion (Gill et al., 2019). 
The initial management should involve careful assessment of the extent of injury, careful assessment of symptoms and signs (Katz and Kluger, 2015). The gold standard tool in assessment of mucosal damage is esophagogastroduodenoscopy (EGD) within the first 12-48h hours of the incident (Bahrami-Motlagh et al., 2017). However, Ain Shams University hospitals policy didn't include this technique as a routine study for diagnosis with relying on clinical assessment and further barium study three weeks post ingestion.

Kamat et al., (2019) study justified the advantages of computed tomography (CT) scan like its availability, feasibility, non-invasiveness and the ability to evaluate the extra GIT involvement. Moreover, they added that, not only helps, assessing the length of involvement of the structured segment of esophagus and stomach but also gives information of pulmonary infiltration and surrounding thoracic soft tissue involvement.

\section{Aim of the Work}

The current study aimed to evaluate the role of MultiDetector Computed Tomography (MDCT) as an early predictor for esophageal injury following acute caustic ingestion and compare it with DROOL score, for patients admitted to PCCASUH.

\section{Subjects and Methods}

This is a prospective cohort study on fifty acute caustic ingestion cases. All symptomatic cases hemodynamically stable within 24 hours post ingestion of caustic agent of both sex aged from (one to 50) year old admitted to PCCASUHs from June 2018 to October 2019 were included. All asymptomatic patients for 24 hours post ingestion, hemodynamically unstable, those exposed to corrosive agent by other routs than ingestion and who presented with delay time more than 24 hours were excluded.

The following data for each patient was obtained and recorded in a special sheet designed:

History taking, clinical examination and DROOL score were applied on admission and during hospital stay mainly the first 48 hours of ingestion. DROOL score used to predict esophageal injury as defined by by Uygun et al. (2012) which included drooling of saliva, reluctance to eat or dysphagia or food intolerance, oral and oropharyngeal lesions and other symptoms and sign as persistent fever, hematemesis, abdominal tenderness, and dyspnea inaddition to high TLC. Score $\leq 4$ indicates high risk of Esophageal injury, while Score $>4$ indicates low risk of Esophageal injury. Total Leucocytic Count (TLC) were done at time of admission and routinely during hospital stay.

MDCT with contrast was done for all patients during the first 24 hours using an Optima CT660 64slice CT scanner with a slice thickness of $0.625 \mathrm{~mm}$ that was more efficient and flexible use of contrast medium than single-detector CT and achieved dose reductions of up to $40 \%$ while maintaining image quality. Creatinine was done for all patients before the maneuver. CT grading system as defined by Ryu et al., (2010) was applied to predict esophageal injury.

Barium study Barium swallow study was done at least 3 weeks after caustic ingestion to diagnose stricture, fibrosis or any other abnormality. Barium study was done for all cases with only $30 \%$ of asymptomatic cases. Although most of asymptomatic cases attended the follow up at PCCASUH outpatient clinic, they refused barium study and didn't show up on the scheduled day.

Esophageal injury follow-up evaluation was performed on PCCASUH outpatient at 1month, 6 months, and one year after ingestion. Cases were classified into; those had esophageal injury and others had No esophageal injury which was based on clinical assessment mentioned above and confirmed by barium study three weeks later. In our study, patients were considered to have esophageal stricture when they have barium swallow study showing esophageal stricture. Diagnosis of oesophageal scarring was based on barium swallow study showing esophageal irregularity in the form of eccentric narrowing denoting asymmetric scarring. Gastro-esophageal reflux disease (GERD) was diagnosed on the basis of symptoms and trial of acid reduction therapy

Statistical analysis:

All obtained data were revised, coded and organized for statistical analysis using IBM SPSS (Statistical package for Social Science) version (23). Data were presented and suitable analysis was done according to the type of data obtained for each parameter. Areas under (ROC) curves was used to compare the CT grading system and DROOL score which varied between 0.5 and 1.0 , a curve area of 1.0 representing perfect test accuracy.

Ethical Consideration:

An informed written consent has been obtained from each patient caregiver before inclusion in the study for obtaining medical history, clinical examination, taking blood samples for laboratory investigations, and performing MDCT scan and barium study (whenever possible), keeping the patient's confidentiality by keeping them anonymous. Approval of Ethical Committee and the Director of PCC-ASUH were also obtained.

\section{Results}

Table (1) and Figure (1) showed that only (25.6\%) of the patients included in the current study had esophageal injury while $(74.4 \%)$ of them had no esophageal injury. It also showed that $(74.4 \%)$ of the cases had esophageal injury, (20.9\%) of the cases developed esophageal stricture, $(2.3 \%)$ of the cases developed GERD and (2.3\%) also developed irregularity denoting fibrosis or scarring with no stricture.

Figure (2) showed that $64 \%$ of the patients DROOL score was $\leq 4$ while only $36 \%$ was $>4$. Also, Figure (3) showed CT grades of cases most of them (31cases), 62\% had grade II injury (edematous thickening of the wall $>3 \mathrm{~mm}$ without periesophageal soft tissue infiltration. (26\%) of cases (13 cases) had grade III injury (edematous thickening of the wall 
$(>3 \mathrm{~mm})$ with periesophageal soft tissue infiltration and well-demarcated tissue interface). 3 cases $(6 \%)$ had grade I injury (no definite thickening of esophagus wall (maximum thickness of $3 \mathrm{~mm}$-normal range). 3 cases $(6 \%)$ had grade IV injury (edematous thickening of the wall with periesophageal soft tissue infiltration and blurring of tissue interfaces or localized adjacent fluid collections around the esophagus or the descending aorta).

Table (2) showed that, among the patients who underwent barium study, (52.4\%) showed no esophageal stricture, however, (42.5\%) showed esophageal stricture and only (4.8\%) had esophageal wall irregularities denoting fibrosis or scarring with no stricture.

Table (3) and Receiver Operating Characteristic curve (ROC) compared the sensitivity and specificity of the MDCT grading system and DROOL score in predicting esophageal stricture. it showed that DROOL score $(\leq 4)$ can predict development of esophageal injury with sensitivity of $(90.9 \%)$, specificity of $(81.2 \%)$ and accuracy of $(83.7 \%),(62.5 \%)$ positive and $(96.3 \%)$ negative predictive values. Also MDCT grades III and IV can predict development of esophageal injury with sensitivity of (90.9\%), specificity of $(87.5 \%)$ and accuracy of $(88.4 \%)$, (71.4\%) positive and $(96.6 \%)$ negative predictive values. ROC curves for the MDCT grading and DROOL scoring system for development of esophageal stricture are presented in Fig. (4). Area under curve for MDCT grading system was $=0.88$, larger than that for the DROOL scoring system was $=0.83$.

Table (1): Types of esophageal injury among cases in the current study

\begin{tabular}{|c|c|c|c|}
\hline \multicolumn{2}{|c|}{} & No. $=\mathbf{4 3}$ & \multicolumn{1}{c|}{$\%$} \\
\hline \multirow{3}{*}{$\begin{array}{c}\text { Type of } \\
\text { esophageal injury }\end{array}$} & No esophageal injury & 32 & $74.4 \%$ \\
\cline { 2 - 4 } & Stricture & 9 & $20.9 \%$ \\
\cline { 2 - 4 } & GERD & 1 & $2.3 \%$ \\
\cline { 2 - 4 } & Irregularity denoting fibrosis or scarring with no stricture & 1 & $2.3 \%$ \\
\hline
\end{tabular}

Table (2): Barium results of cases in the current study.

\begin{tabular}{|c|c|c|c|}
\hline \multicolumn{2}{|c|}{} & No. = 21 & \multicolumn{2}{c|}{$\%$} \\
\hline \multirow{3}{*}{ Barium result } & No stricture & 11 & $52.4 \%$ \\
\cline { 2 - 5 } & Stricture & 9 & $42.9 \%$ \\
\cline { 2 - 5 } & Irregularity denoting fibrosis or scarring with no stricture & 1 & $4.8 \%$ \\
\hline
\end{tabular}

Table (3): Diagnostic accuracy of DROOL score and CT grading in predicting the incidence of esophageal injury among cases in the current study.

\begin{tabular}{|c|c|c|c|c|c|}
\hline Parameter & Accuracy & Sensitivity & Specificity & PPV & NPV \\
\hline DROOL score $\leq \mathbf{4}$ & 83.7 & 90.9 & 81.2 & 62.5 & 96.3 \\
\hline CT grade $($ III\&IV) & 88.4 & 90.9 & 87.5 & 71.4 & 96.6 \\
\hline
\end{tabular}

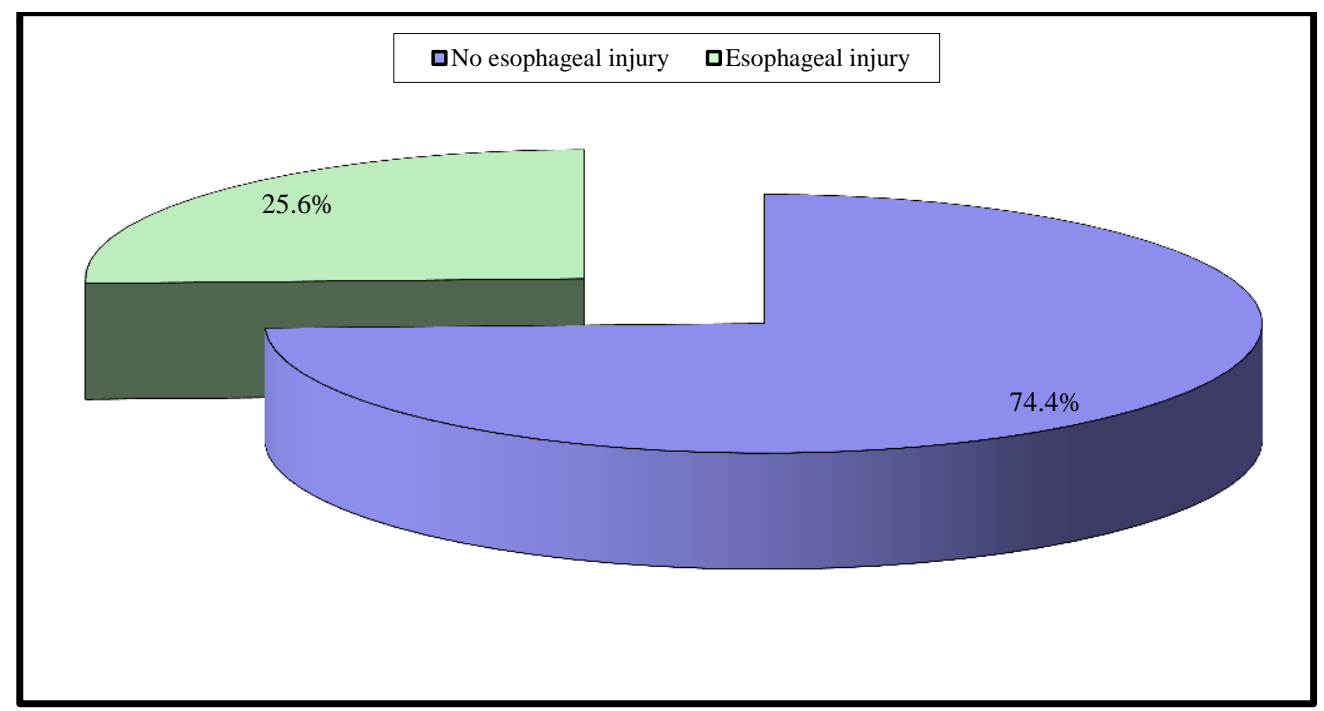

Fig (1): Percentage of esophageal injury among cases in the current study. 


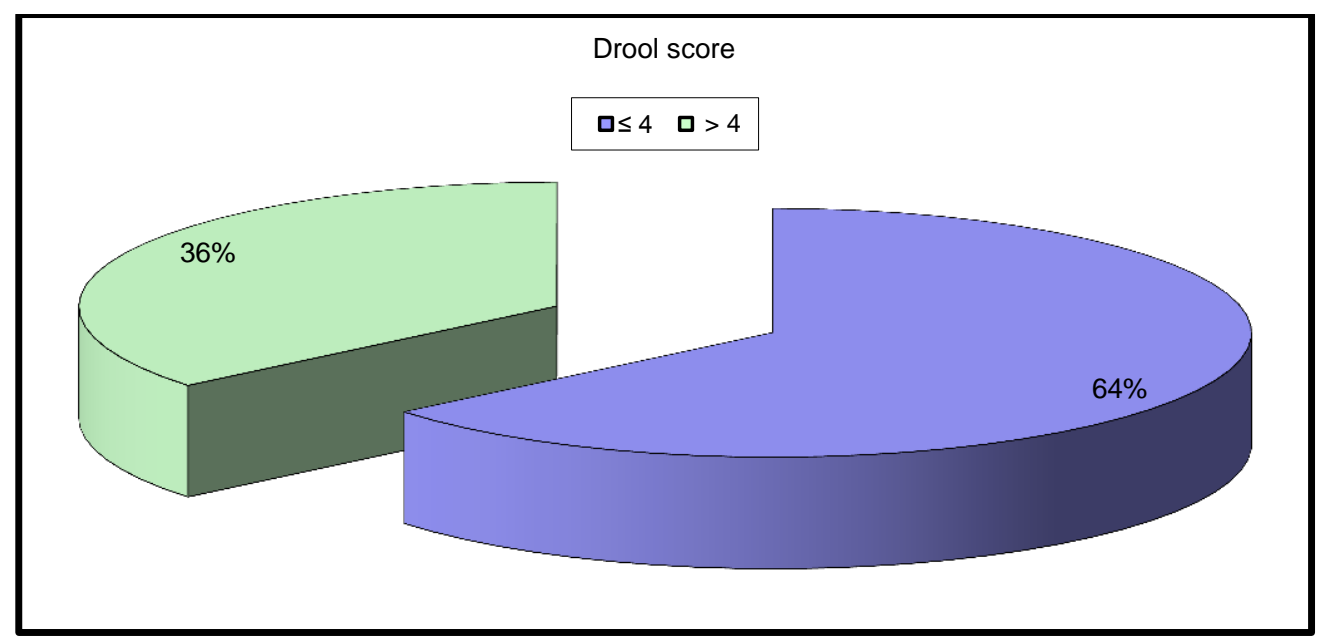

Figure (2): DROOL scores of cases in the current study.

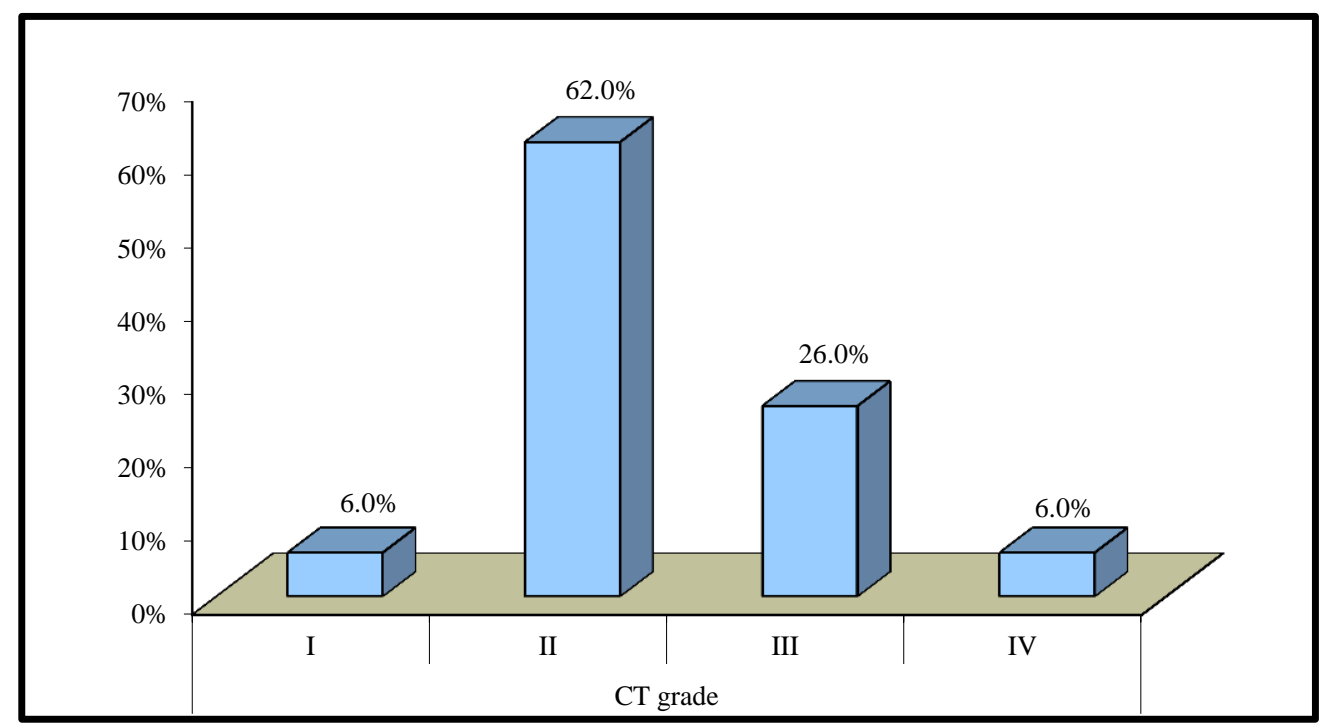

Figure (3): CT grades of cases in the current study.



Figure (4): Receiver operating characteristic (ROC) curve displaying the diagnostic accuracy of DROOL score and CT grading in predicting the development of esophageal injury among cases in the current study. 


\section{Discussion}

Ingestion of caustic substances is a serious problem associated with not only major health consequences but also leads to family break-ups, abandonment, and job losses (Gill et al., 2019, Povilavičius et al., 2019. Stricture formation is the most common and disabling long-term complication of corrosive ingestion that can be predicted if earlier follow up and intervention before collagen deposition make therapeutic interventions more difficult (Gill et al., 2019).

Although the gold standard; endoscopy has been used in predicting the risk of stricture formation after caustic injuries, Yet, the ability of Zargar classification to predict stricture formation remains controversial and varies studies showed that it is outperformed by CT (Chirica et al.,2019). It has many limitations, and finding an alternatives-preferably non-invasive for detection of probable mucosal injuries following caustic ingestion is an area of researchers' interest. With the wide availability of computed tomography (CT) $24 \mathrm{~h}$ a day, compared with limited endoscopic services, the use of CT to augment, if not supersede, endoscopic assessment is a reasonable consideration (Bahrami-Motlagh et al.,2017 and Gill et al.,2019).

This study is a prospective cohort study carried out on 50 patients admitted to poison PCCASUH with history of corrosive ingestion within the previous 24 hours during the period from June 2018 to October 2019. It aimed to evaluate the role of MDCT as an early predictor for esophageal injury following acute caustic ingestion and compare MDCT grading system and DROOL score, for predicting the outcome of patients with caustic ingestion.

The study recorded that, $(25.6 \%)$ of the patients had esophageal injury while $(74.4 \%)$ of them had no esophageal injury. Esophageal injuries included stricture, scarring and gastro-esophageal reflux disease (GERD) with the most common was stricture formation which found in $(20.9 \%)$ of cases that was diagnosed clinically and confirmed by Barium study. Followed by GERD which was reported in $(2.3 \%)$ of cases and diagnosed on clinical basis. However, esophageal scarring with no stricture found in $(2.3 \%)$ of cases and was diagnosed only by barium study. This goes hand in hand with Ciammaichella et al., (2019) who stated that, stricture formation is the most common late post-corrosive complication. This also was in agreement with the result of Mahmoud et al., (2019) in which who found that, most common postcorrosive complication was stricture formation which occurred in $(18.5 \%)$ of cases. Moreover, Bruzzi et al., (2018) and Kumar et al., (2019), showed that, (37\% and $12.8 \%$ respectively) of patients developed esophageal strictures. In contrary, study of Cowan et al., (2017) that aimed to determine the incidence of esophageal strictures in corrosive ingestions, reported only $(3 \%)$ of cases developed stricture. Chibishev et al., (2012) explained the differences in the reported incidence of strictures among studies to the differences of age, types or forms of ingested substances and it may be also related to how the stricture was defined.
Cheng et al. (2008), using a combination of patient's symptoms and imaging (like the current study) and reported an incidence of (24\%), however, Kochhar et al., (2017) and Kumar et al., (2019) depended solely on barium study. On contrary, studies done by Bruzzi et al., (2018) and Le Naoures et al., (2017), barium and endoscopy were done only for patients with symptoms of stricture (pain, dysphagia, etc...).

Prediction of the severity of injury following ingestion of caustic agents was a challenging problem for clinicians, as rapid assessment is important because the prognosis depends on early application of appropriate treatment (Mahmoud et al., 2019). To predict esophageal injury in our study, we used DROOL score and CT grading system as defined by Uygun et al. (2012and Ryu et al., (2010) respectively.

The study showed that, DROOL score in $64 \%$ of the patients were $\leq 4$ while only $36 \%$ of patients had score $>4$. Also the study showed that, DROOL at cutoff of $\leq 4$ could predict esophageal injury with sensitivity $(90.9 \%)$, specificity $(81.2 \%)$ and accuracy $(83.7 \%)$. This was similar to Uygun et al., (2012) study, who found that, DROOL at a cutoff of $\leq 4$ could predict esophageal stricture with sensitivity $(100 \%)$, specificity $(96 \%)$ with limitations that it included children. Brusin and Krayeva (2012) also reported that, the presence of severe manifestations following caustic ingestion as laryngeal edema, pneumonia and gastrointestinal bleeding were associated with significant tissue damage and high endoscopic grading and more risk for the occurrence of stricture. Moreover, Grace et al., (2013) reported that, the presence of vomiting, hyper salivation, hoarseness of voice were associated with significant gastro-esophageal injury they added that, there was relation between the presence or absence of three serious signs and symptoms (vomiting, drooling and stridor) and the endoscopic grading, thus can predict the degree of gastrointestinal injury. On the opposite side, a study done by Sharif et al., (2021) who reported that the best cut off point for Drool Score to predict esophageal injury in corrosive patients was not (4) but (6.5). Also, Mahmoud et al., (2019) study found that the best cut off point for Drool Score to predict stricture formation in corrosive patients was not 4 but 5.5 which achieved $(88 \%)$ sensitivity with $(69.1 \%)$ specificity and that might mean lower sensitivity and specificity for the cut off level (4).

Moreover, the study used CT grading system for esophageal injury prediction with most of the cases (31cases), 62\% had grade II injury (edematous thickening of the wall $>3 \mathrm{~mm}$ without periesophageal soft tissue infiltration. (26\%) of cases (13 cases) had grade III injury (edematous thickening of the wall $(>3 \mathrm{~mm})$ with periesophageal soft tissue infiltration and well-demarcated tissue interface). 3 cases (6\%) had grade I injury (no definite thickening of esophagus wall (maximum thickness of $3 \mathrm{~mm}$-normal range). 3 cases (6\%) had grade IV injury (edematous thickening of the wall with periesophageal soft tissue infiltration and blurring of tissue interfaces or localized adjacent fluid 
collections around the esophagus or the descending aorta). It also showed that MDCT was a discriminant predictor for esophageal injury after caustic ingestion with specificity $(87.5 \%)$, sensitivity $(90.9 \%)$ and accuracy (88.4\%). The absence of CT grade III and IV has $(96.6 \%)$ positive predictive value, meaning that few strictures would be missed if grade I and II on CT are treated conservatively.

This was similar to Ryu et al. (2010) and Bonnici et al., (2014) studies result who found that, CT to be better than endoscopy in predicting the risk of stricture formation, with a sensitivity and specificity $(81.4 \%)$ of $(95.6 \%)$ respectively for CT compared with $(62.8 \%)$ and $(84.8 \%)$, respectively for endoscopy. Our work results also in agreement with the results of a 10 year-prospective cohort study by Bruzzi et al., (2018) which compared the accuracy of CT-scan versus endoscopy of 152 adult patients at risk of developing esophageal stricture following corrosive ingestion. They reported that, not only CT classification alone was equal to a combined CT-scan-endoscopy classification but also, CT-scan was more efficacious than acute endoscopy for predicting which patients were at risk for developing esophageal strictures. They also, added that endoscopy might be dispensed with and that the decision to perform surgery in caustic ingestion can safely rely on $\mathrm{CT}$ alone. Moreover, Gill et al., (2019) stated that esophageal and gastric CTscan is better than traditional endoscopy for assessing the risk of stricture formation. Yet, the ability of Zargar endoscopic classification of caustic injuries to predict stricture formation remains controversial and is outperformed by CT (Gill et al., 2019, Chirica et al., 2019). Added to the advantage for CT mentioned before, the current study, reported one patient developed Gastro-esophageal reflux disease (GERD) in the form of (vomiting and regurgitation that started 3 months of caustic ingestion). It was noted that CT of this patient showed grade IV (Edematous thickening of the wall with periesophageal soft tissue infiltration and blurring of tissue interfaces or localized adjacent fluid collections around the esophagus or the descending aorta). On the other side, Barium study result done after one month was normal. It was repeated again after 1 year and was also normal although the patients suffered from increased frequency and severity of symptoms. Barium study gave false negative result twice for this patient and couldn't diagnose the presence of GERD. This might mean CT could predict occurrence of esophageal injury in this patient while Barium couldn't. This was also explained by De Lusong et al., (2017) and Hall et al., (2019) studies who stated that, secondary damage due to gastroesophageal reflux may aggravate existing mucosal injury, thus accelerating stricture formation. It leads to stricture in (7-23\%) of untreated cases. Moreover, acid reflux can adversely affect the response to the treatment of stricture making it refractory to dilatation. Likewise, Meena et al., (2017) found that a conclusive diagnosis of reflux disease cannot be made by using barium esophagography as it is not sensitive for the detection of motility disorders
Barium study was done on 21 cases and used to detect presence of stricture, stenosis, scarring or any other abnormalities. Although diagnosis of esophageal stricture in our study was based on symptoms and confirmed by Barium study as mentioned by Contini et., al. (2013), unfortunately some parents refused barium study for being asymptomatic. Among patients who underwent Barium study, (52.4\%) showed no esophageal stricture, $(42.5 \%)$ showed esophageal stricture and only (4.8\%) had esophageal wall irregularities denoting fibrosis or scarring with no stricture. This was in agreement with study of Kamat et., al. (2019) who stated that, Barium swallow and barium meal are reliable tests to assess the length, number, and extent of the upper GI stricture in subacute and chronic stage

The study also showed that, CT grading described higher specificity $(87.5 \%)$ in estimating esophageal injury compared with DROOL score $(81.2 \%)$, it also showed higher accuracy $(88.4 \%)$ in estimating esophageal injury compared with DROOL score $(83.7 \%)$. The sensitivity of both systems were the same $(90.9 \%)$. Area under curve (AUC) for CT grading system $(\mathrm{AUC}=0.88)$ was larger than that for DROOL scoring system (AUC $=0.83$ ). So that, ROC curve analysis recorded CT outperformed DROOL score in predicting esophageal injury. Although the difference in specificity and accuracy between CT and DROOL was not statistically significant yet, DROOL score has many limitations. The absence of grade 3 or 4 injury on CT has a negative predictive value of $(93 \%)$, meaning that few stricture would be missed if patients with grade 1 or 2 injuries on CT are treated conservatively. This was proved by Uygun et al., (2012) study who clarified that definite detection of timing of ingestion and start of symptoms which lasted from 12 to 24 hours is a crucial for accurate DROOL score. Others concluded that initial signs and symptoms were not useful predictors for the severity of esophageal injury as mentioned by Sabzevari et al., (2017). They added that, there was clear superiority of the CT grading over the endoscopic grading system as a 'rule-out ' test for the development of esophageal stricture in the early investigations of caustic injuries. Moreover, Bahrami-Motlagh et al. (2017) study on 34 adult patients with corrosive ingestions comparing results of CT-scan versus endoscopy in predicting the extent of upper gastrointestinal tract damage. They found that ROC curve of CT scan in detection of esophagus and stomach mucosal injuries were (0.76) and (0.64), respectively. Sensitivity and specificity of CT-scan for diagnosis of esophageal injury were, respectively, $(96.2 \%)$ and $(57.1 \%)$. Based on these findings of that study, CT scan could be considered as a sensitive tool in screening of upper gastrointestinal mucosal injuries following caustic ingestions. However, Kumar et al., (2019) study included 112 patients, showed that, there was no relationship between the presence of symptoms or oral mucosal injury and the grades of gastrointestinal mucosal injury. This was confirmed recently by Oliva et al., (2020) found that, the imprecise clinical history frequently leaves clinicians uncertain about timing of the ingestion. 
Recently, Sharif et al, (2021) explained the limitation of DROOL score as it mainly related to local oropharyngeal corrosive effects while missing important manifestations such as hoarseness of voice, stridor, chest crepitations and vomiting which considered one of the predictors of poor patients' outcomes. This was also recorded in study done by Mahmoud et al., (2019), who reported vomiting occurred in $(92 \%)$ of cases, chest crepitations in $(23 \%)$ and $(20 \%)$ of these cases developed esophageal stricture later on and were significant predictors of stricture formation.

\section{Conclusion and Recommendations}

The current study concluded that esophageal injury can be highly predicted using CT grading with higher accuracy $(88.4 \%)$ compared with DROOL score $(83.7 \%)$ with larger area under ROC curve compared with DROOL score. It is recommended that, MDCT chest and abdomen to be added to the routine management of patients with caustic ingestion to predict esophageal injury and decide management plan as well. Further studies on $\mathrm{CT}$ in patients with caustic injury for assessing not only esophageal injuries, but also surrounding soft tissues (ex: lung, pleura, stomach) where coexistent injuries may be present.

\section{References}

Agarwal A, Srivastava DN, Madhusudhan KS (2020): Corrosive injury of the upper gastrointestinal tract: the evolving role of a radiologist. $\mathrm{Br} \mathrm{J}$ Radiol.; 93(1114): 20200528.

Azab M.S., Hirshon M.J., Hayes B.D., El-Setouhy M., Smith G.S., Sakr M.S., Tawfik H. and KleinSchwartz W. (2016): "Epidemiology of acute poisoning in children presenting to the poisoning treatment center at Ain Shams University in Cairo, Egypt, 2009-2013" Clinical Toxicology, 2016 VOL. 54, NO. 1, 20-26.

Bahrami-Motlagh H, Hadizadeh-Neisanghalb M, Peyvandi H (2017): Diagnostic Accuracy of Computed Tomography Scan in Detection of Upper Gastrointestinal Tract Injuries Following Caustic Ingestion. Emerg (Tehran).; 5(1):e61.

Bonnici KS, Wood DM, and Dargan PI (2014): Should computerised tomography replace endoscopy in the evaluation of symptomatic ingestion of corrosive substances?. Clinical Toxicology; 52(9): 911-925.

Bruzzi M, Chirica M, Resche-Rigon M, Corte H, Voron T, Safarti E, Zagdanski AM, Cattan P (2018): Emergency computed tomography predicts caustic esophageal stricture formation. Ann Surg Mar.; 12: 109-114.

Brusin K.M. and Krayeva Y.V. (2012): "Highly Concentrated Acetic Acid Poisoning: 400 Cases Reviewed". Asia Pacific Journal of Medical Toxicology. Vol (1): 3-9

Cheng HT, Cheng CL, Lin CH, et al. (2008): Caustic ingestion in adults: the role of endoscopic classification in predicting outcome. BMC Gastroenterol.; 8:31.
Chibishev A, Pareska Z, Chibisheva V and Simonovska N (2012): Clinical and epidemiological features of acute corrosive poisonings. Medical Archives; 66(3):11-15.

Chirica M, Kelly M D, Siboni S et al. (2019): Esophageal emergencies: WSES guidelines. World Journal of Emergency Surgery; 14:26

Ciammaichella MM, Galanti C, Rossi C (2019): Caustic ingestion. emergency medicine journal [Accessed 03/21/2019].http://www.emjournal.net/htdocs/pa ges/art/47-caul.html

Contini S and Scarpignato C (2013): Caustic injury of the upper gastrointestinal tract a comprehensive review. World Journal Gastroenterology; 19(25): 3918-3930.

CowanT., Foster R., and K.Isbister G.K. (2017): "Acute esophageal injury and strictures following corrosive ingestions in a 27 year cohort". The American Journal of Emergency Medicine Volume 35, Issue 3, Pages 488-492.

De Lusong MAA, Timbol ABG, Tuazon DJS (2017): Management of Esophageal Caustic Injury. World J Gastrointest Pharmacol Ther; 8(2):9098.

Gill A, Tee D and Chinnaratha MA (2019): Caustic ingestion: Has the role of the gastroenterologist burnt out?. Emergency medicine Australia; 31(3): 297-500.

Grace C, Dioquino C and Pascual J (2013): Predictive Factors of Gastrointestinal Caustic Injury According to Clinical and Endoscopic Findings. Asia Pacific Journal of Medical Toxicology; 2(1):19-22.

Hall AH, Jacquemin D, Henny D, Mathieu L, Josset P, Meyer B (2019): Corrosive substances ingestion: a review, Critical Reviews in Toxicology; 49(8): 637-669.

Kamat R, Gupta P, Reddy YR, Kochhar S, Nagi B, Kochhar R (2019): Corrosive injuries of the upper gastrointestinal tract: a pictorial review of the imaging features. The Indian journal of radiology \& imaging; 29(1):6.

Katz A and Kluger Y (2015): Caustic material ingestion injuries-paradigm shift in diagnosis and treatment. Health Care Current Reviews; 3:1-4.

Kochhar R, Ashat M, Reddy YR, Dhaka N, Manrai M, Sinha SK, Dutta U, Yadav TD, Gupta V (2017): Relook endoscopy predicts the development of esophageal and antropyloric stenosis better than immediate endoscopy in patients with caustic ingestion. Endoscopy.; 49(7):643-650.

Kumar C B., Chowdhury SD, Ghatak SK, Sreekar D, Kurien RT, David D, Dutta AK, Simon EG, Joseph AJ (2019): Immediate and long-term outcome of corrosive ingestion. Indian $\mathbf{J}$ Gastroenterol.; 38(4):356-361.

Le Naoures P, Hamy A, Lerolle N, Métivier E, Lermite E, Venara A (2017): Risk factors for symptomatic esophageal stricture after caustic ingestion-a retrospective cohort study. Dis Esophagus.; 30(6):1-6. 
Mahmoud A.E, Mohammed E.A, Al Husseini R and Bilal SI (2019): Risk Factors Predicting Stricture Formation and Death in Patients with Caustic Ingestion. Ain Shams Journal of Forensic Medicine and Clinical Toxicology; 32: 10-19.

Meena BL, Narayan KS, Goyal G, Sultania S, Nijhawan S (2017): Corrosive injuries of the upper gastrointestinal tract. Journal of Digestive Endoscopy; 8(4): 369.

Oliva S, Romano C, Norsa L (2020): Foreign body and caustic ingestions in children: A clinical practice guideline: Foreign Bodies and Caustic ingestions in children. Digestive and Liver Disease; 52(11):1266-1281.

Povilavičius J, Samalavičius NE, Verkauskas G, Trainavičius K, Povilavičienè M (2019): Conservative treatment of caustic oesophageal injuries in children: 15 years of experience in a tertiary care paediatric centre. Przeglad gastroenterologiczny, 14(4): 286-291.

Ryu H.H. 1, JeungK.W., Lee B.K., Uhm J.H., Park Y.H., Shin M.H., Kim H.L., Heo T., and Il Min Y. (2010): "Caustic injury: can CT grading system enable prediction of esophageal stricture?. Clin Toxicol (Phila) Feb;48(2):137-42.

Sabzevari A., Maamouri G., Ali Kiani M., Saeidi M., Kianifar H., Jafari A.S., Ahanchian H., Jarahi L., Roudi E.,2 and Sharafkhani M. (2017): "Clinical and endoscopic findings of children hospitalized in Qa'em Hospital of Mashhad due to caustic ingestion (2011-2013)". Electron Physician. Apr; 9(4): 4248-4250.

Sharif AF, Gameel DEGE, Abdo SAE, Elgebally EI, Fayed MM (2021): Evaluation of Pediatric Early Warning System and Drooling Reluctance Oropharynx Others Leukocytosis scores as prognostic tools for pediatric caustic ingestion: a two-center, cross-sectional study. Environmental Science and Pollution Research; $1-18$.

Uygun I, Aydogdu B, Okur M, Arayici Y, and Celik Y, Ozturk H and Otcu S (2012): Clinicoepidemiological study of caustic substance ingestion accidents in Children in Anatolia: the DROOL score as a new prognostic tool. Acta chirurgica Belgica; 112:346-354.

\title{
هل الأشعه المقطعية متعدد المقاطع اداة تثخيصية جيدة ككاشف مبكر لإصابة المريء نتيجة تناول المواد الكاوية جئة
}$$
\text { 'أميرة ياسين عبد القادر' و منال علي عبد الكريم' و خالد ابو الفتوح احمد وهند محمد عبد الرحمن الهلالي' }
$$$$
\text { الملخص العربى }
$$ \\ مقدمة: ان تناول المواد الكاويه حالة متكررة في الطوارئ و التنبؤ المبكر بسوء الحالة أمر ضروري لاتخاذ القرار المبكر و تحسين خطة العلاج. حتي الآن , لا يوجد \\ في مستشفياتنا كاشف مبكر لاصابة المريء في حالات تناول المواد الكاوية. \\ يهدف هذا العمل إلى تقييم دور الأشعة المقطعية متعددة المقاطع ككاشف مبكر لإصابة المريء نتيجة تناول المواد الكاوية كما يهدف الي اختبار فاعلية نظام \\ التقييم القائم علي الأشعة المقطعية بالمقارنة بمعيار "درول" في تقييم درجة الحالة و التنبؤ بالنتائج. \\ الطريقة: تم عمل دراسة مستقبلية تضمنت خمسين حالة تم حجزهم بمركز السموم الإكلينيكي الخاص بمستشفيات جامعة عين شمس أثر تناول مادة كاويه خلال

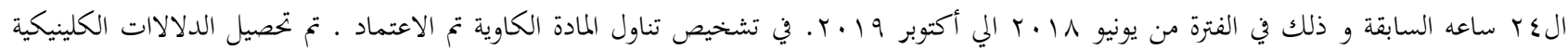 \\ ووضع تدريج للتقييم بالأشعه المقطعية ومقارنتها بتدريج الأعراض الخاصة بمقياس DROOL الأكلينيكي تم عرض النتيؤئج في صورة جداول بيانية مع تحليلها \\ احصائيا و كانت النتائج كما يلي: \\ تم تحليل النتائج إحصائياً

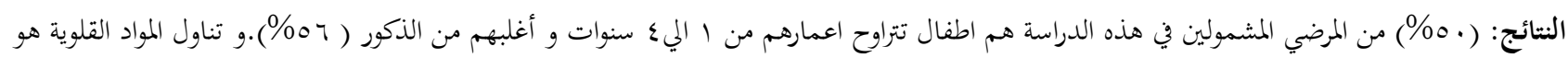





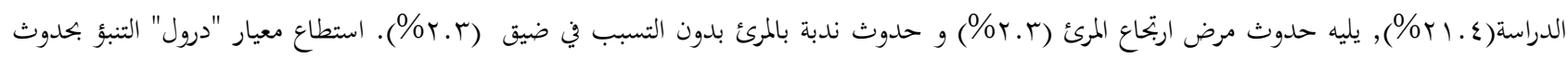 \\ اصابه بالمرئ بحساسيه واحد و ثمانون و اثنين من عشره في المائه و دقه ثلاثة و ثمانون و سبعة من عشرة في المائة. و استطاع ايضا نظام التقييم الخاص بالاشعه




عشرة في المائة. خمسة و عشرون و سته من عشره في المائه من المرضي الذين شملتهم هذه الدراسه حدثت لديهم اصابه بالمرئ بينما اربعة و سبعون و اربعه من

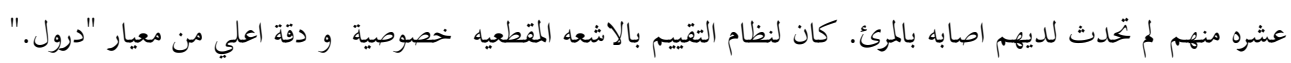
المستخلص والتوصيات: الأعتماد علي تدريج الدلالات في الأشعه المقطعية لدي المرضي المعرضون لتسمم المواد الأكلة الحادة بالفم اثبت دقة في التقييم

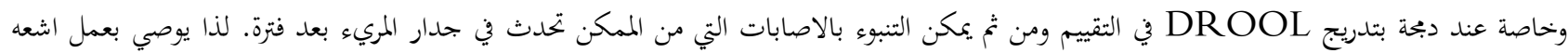

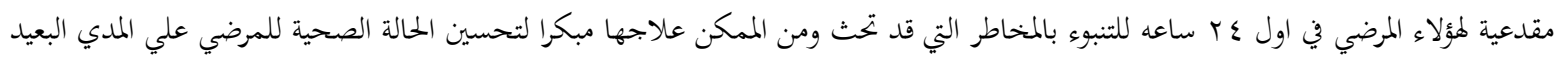

